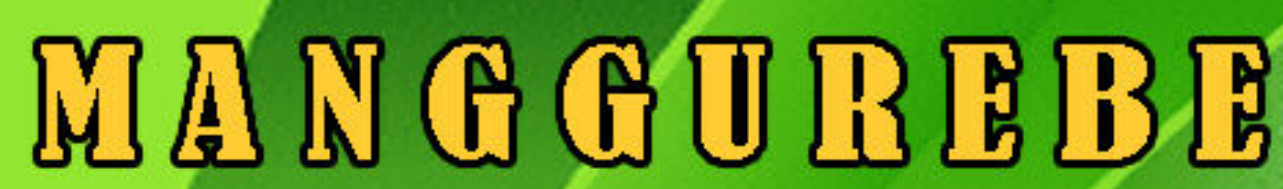
Journal Physical Education, Health and Recreation

Diterbitkan oleh:

Program Studi Pendidikan jasmani kesehatan dan Reldreasi Universitas Pattimura

Jalan. Ir M. Putuhena, Poka-Ambon 


\title{
MENINGKATKAN KEMAMPUAN BELAJAR ROLL DEPAN MELALUI METODE DRILL PADA SISWA SMK NEGERI 7 AMBON \\ Junita Elwuar ${ }^{1}$ Johanna Matitaputty ${ }^{2}$ \\ Program Study PJKR FKIP UNPATTI Ambon, \\ Jokematitaputty01@gmail.com
}

\begin{abstract}
ABSTRAK
Peneliti merencanakan perbaikan permasalahan dengan menerapkan metode drill pada pembelajaran gerakan meroda. Diterapkannya metode drill dalam mengatasi masalah ini dengan pertimbangan bahwa metode drill adalah metode pembelajaran dengan cara pengulanganpengulangan gerakan dengan tujuan terjadinya gerakan yang baik dan benar secara otomatisasi. Sehingga guru langsung bisa mengontrol gerakan yang dilakukan oleh siswa-siswi tersebut. Berdasarkan fakta empiris yang ditemui dilapangan, maka penulis tertarik untuk melakukan penelitian dengan judul "meningkatkan hasil belajar meroda melalui penerapan metode drill pada siswa-siswi kelas x smk negeri 7 ambon Berdasarkan nilai-nilai dari siklus I dan siklus II dapat disimpulkan untuk siklus I pembelajaran belum berhasil karena belum memenuhi standar ketuntasan KKM. Dari jumlah keseluruhan siswa baik dalam aspek kognitif, afektif maupun psikomotor. Pada siklus I pembelajaran sudah berjalan dengan baik, anak sudah antusias dalam pembelajaran akan tetapi siswa masih belum serius dalam mengikuti pembelajaran dan masih ada yang takut atau kurang percaya diri. Sedangkan pada siklus II nilai pembelajaran lebih meningkat karena adanya perbaikan dalam pembelajaran sehingga siswa mampu mencapai KKM $\geq 75$.
\end{abstract}

Kata Kunci: Kemapuan Belajar, Roll Depan, Metode Drill 


\section{A. PENDAhUluan}

Menurut Agus Margono (2009), senam lantai yaitu latihan senam yang dilakukan di atas matras, unsur-unsur gerakannya terdiri dari mengguling, melompat, meloncat, berputar di udara, menumpu dengan tangan atau kaki untuk mempertahankan sikap seimbang atau pada saat meloncat ke depan atau ke belakang. Senam memiliki beragam gerak yang sangat komplek, antara lain guling ke depan, guling ke belakang, sikap lilin, meroda, dll.

Salah satu materi senam yang diajarkan di sekolah adalah gerakan meroda. Gerakan meroda menurut Suyati, dkk (1994) adalah suatu gerakan ke samping pada saat bertumpu atas kedua tangan dengan kaki terbuka besar atau kangkang. Namun siswa-siswi SMK Negeri 7 Ambon belum mampu melakukan gerakan meroda dengan baik. Walaupun guru sudah memberikan tugas untuk berlatih dirumah, tetapi kenyataan, mereka belum mampu melakukan gerakan meroda dengan baik.

Selain kendala tesebut berdasarkan hasil survei awal yang peneliti lakukan terdapat juga kendala seperti sebagian besar siswa masih belum terlihat aktif dalam proses pembelajaran, kurangnya motivasi siswa dalam pembelajaran, pembelajaran masih kurang menarik, siswa tidak mengulagi gerakan di rumah walaupun telah diberikan tugas oleh guru.

Untuk mengatasi permasalahan tersebut peneliti merencanakan perbaikan permasalahan dengan menerapkan metode drill pada pembelajaran gerakan meroda. Diterapkannya metode drill dalam mengatasi masalah ini dengan pertimbangan bahwa metode drill adalah metode pembelajaran dengan cara pengulangan-pengulangan gerakan dengan tujuan terjadinya gerakan yang baik dan benar secara otomatisasi. Sehingga guru langsung bisa mengontrol gerakan yang dilakukan oleh siswa-siswi tersebut.

Berdasarkan fakta empiris yang ditemui dilapangan, maka penulis tertarik untuk melakukan penelitian dengan judul "Meningkatkan hasil belajar meroda melalui penerapan metode Drill pada Siswa-siswi kelas X SMK Negeri 7 Ambon.

\section{B. METODOLOGI PENELITIAN}

Jenis penelitian ini adalah penelitian tindakan (Class Action Research), dan menggunakan metode Penelitian Tindakan Kelas (PTK). Menurut Agus Kristianto (2010) yakni penelitian tindakan yang diawali dengan perencanaan, pelaksanaan, observasi, dan refleksi.

Penelitian Tindakan Kelas (PTK) ini direncanakan tiga siklus, untuk mengetahui peningkatan hasil belajar meroda pendidikan jasmani, olahraga dan kesehatan dengan metode drill, siklus terdiri dari empat langkah yaitu perencanaan, pelaksanaan tindakan, observasi dan refleksi.

\section{Populasi Dan Sampel}

Subjek dalam penelitian ini adalah keseluruhan siswa kelas $\mathrm{X}$ jurusan multimedia

\section{Instrumen Penelitian}

Istrumen yang digunakan dalam penelitian ini adalah:

1. Rencana Pelaksanaan Pembelajaran (RPP)

2. Rubrik Penilaian. 


\section{E. Teknik Pengumpulan Data}

Dalam penelitian ini pengumpulan data dilakukan dengan menggunakan langkah-langkah sebagai berikut:

1. Prosedur Administrasi

a. Mengurus surat ijin penelitian

b. Melakukan koordinasi dengan pihak sekolah tempat penelitian

c. Melakukan survei awal

d. Menyiapkan alat-alat penunjang penelitian

e. Menyiapkan tenaga pembantu

f. Memberikan penjelasan kepada siswa

g. Menjelaskan maksud dan tujuan penelitian

h. Pelaksanaan siklus pertama

i. Memberikan pembelajaran dengan metode demonstrasi

j. Pelaksanaan siklus kedua

k. Setelah hasil tes akhir pada siklus kedua sudah baik maka tidak lagi dilanjutkan pada berikutnya

1. Setelah data terkumpul kemudian akan diolah dengan menggunakan rumus statistik.

2. Prosedur pelaksanaan (pembelajaran)

Dalam pelaksanaan pembelajaran maka peneliti membuat RPP dengan materi senam lantai dan metode yang digunakan adalah metode drill (RPP terlampir).

3. Prosedur pengukuran

Proses pengukuran dalam penelitian ini menggunakan rubrik penilaian sebagai berikut:

a. Pemahaman konsep gerak

b. Teknik penilaian kognitif

c. Teknik penilaian unjuk kerja

\section{F. Hasil Dan Pembahasan}

dijelaskan bahwa dengan menerapkan metode pembelajaran drill diperoleh nilai rata-rata kemampuan belajar siswa $74,40 \%$. Siswa yang sudah tuntas belajar mencapai $56,25 \%$ atau ada 18 siswa dan $43,75 \%$ siswa yang belum tuntas belajar atau ada 14 siswa yang belum mencapai ketuntasan belajar. Hasil tersebut menunjukan bahwa pada siklus pertama siswa belum tuntas belajar, karena siswa yang memperoleh nilai $\geq 75$ hanya sebesar 56,25 \% lebih kecil dari presentase ketuntasan yang di kehendaki yaitu 75\%. Hal ini disebabkan karena siswa merasa belum mengerti dan memahami apa yang dimaksudkan dan digunakan guru dengan menerapkan proses pembelajaran dengan metode drill.

Berdasarkan tabel diatas menunjukan bahwa setelah melakukan tes pada siklus II dan didapat hasil adalah yang berada diatas KKM sebanyak 32 siswa (100\%) siswa yang telah tuntas dan yang berada dibawa KKM sebanyak $0(0 \%)$ yang belum tuntas.

Itu berarti pada Pertemuan siklus II proses tindakan telah berjalan dengan lancar. Guru menyampaikan materi dengan baik. Peserta didik juga dapat dikondisikan dengan baik. Semua siswa mengikuti pembelajaran dari awal hingga akhir tindakan. Hasil pada siklus II ini 
mengalami peningkatan lebih baik dari siklus I. Adanya peningkatan kemampuan belajar pada siklus II ini di pengaruhi oleh adanya peningkatan kemampuan guru dalam menerapkan metode pembelajaran drill sehingga siswa menjadi lebih terbiasa dengan pembelajaran seperti ini sehingga siswa lebih mudah dalam memahami materi yang telah diberikan. Disamping itu juga ketuntasan ini dipengaruhi oleh kerjasama dari siswa yang telah menguasai materi pembelajaran untuk membantu temannya.

Berdasarkan pelaksanaan tindakan maka hasil observasi nilai dapat dikatakan pada pertemuan pertama kegiatan pembelajaran belum berhasil, karena dalam proses belajar mengajar masih terlihat siswa yang bermain, berceritra, dan saling menganggu satu sama yang lain. Penggunaan metode pembelajaran drill dalam peningkatan prestasi belum tampak, sehingga hasil belajar siswa yang dicapai belum maksimal atau belum tuntas. Proses pembelajaran yang dilakukan dianggap hal yang baru, dan baru mereka laksanakan sehingga siswa merasa kaku dalam melaksanakannya.

Proses pelaksanaan pembelajaran pada siklus II, mereka dapat mengerti dan buktinya proses kegiatan pembelajaran berjalan dengan baik, siswa semua aktif dan mendapatkan hasil yang baik sesuai dengan kriteria ketuntasan yang ditentukan dari sekolah tersebut. Pada siklus I hasil belajar siswa dalam melakukan pembelajaran senam lantai meroda adalah sebagai berikut: Siswa yang telah mencapai Kriteria Ketuntasan Maksimal adalah 18 siswa dan yang belum tuntas adalah 14 siswa sehingga keberhasilan pada siklus I adalah yang tuntas 56,25\% dan yang belum tuntas adalah $43,75 \%$.

Sedangkan hasil belajar siswa pada siklus II adalah sebagai berikut: Siswa yang telah mencapai KKM adalah 32 siswa dan yang di bawah KKM adalah 0 siswa, sehingga keberhasilan pada siklus II adalah $100 \%$ dan siswa yang belum tuntas 0\%. Dari siklus I yang presentase ketuntasannya hanya $56,25 \%$ menjadi $100 \%$ berarti ketuntasan hasil belajar siswa mengalami kenaikan sebesar 43,75\%. Demikian dapat dikatakan bahwa pembelajaran telah berhasil karena siswa yang tuntas telah mencapai Nilai KKM.

Berdasarkan nilai-nilai dari siklus I dan siklus II dapat disimpulkan untuk siklus I pembelajaran belum berhasil karena belum memenuhi standar ketuntasan KKM. Dari jumlah keseluruhan siswa baik dalam aspek kognitif, afektif maupun psikomotor. Pada siklus I pembelajaran sudah berjalan dengan baik, anak sudah antusias dalam pembelajaran akan tetapi siswa masih belum serius dalam mengikuti pembelajaran dan masih ada yang takut atau kurang percaya diri. Sedangkan pada siklus II nilai pembelajaran lebih meningkat karena adanya perbaikan dalam pembelajaran sehingga siswa mampu mencapai $\mathrm{KKM} \geq 75$.

Berdasarkan kurikulum 2006 (KTSP) siswa dikatakan tuntas apabila siswa telah mencapai nilai standar KKM. Sedangkan pada penelitian ini, pencapai nilai KKM pada siklus II telah tercapai. Dengan demikian maka hipotesis yang diajukan dapat diterima. 


\section{DAFTAR PUSTAKA}

Abin Syamsudin Makmum, 2000, Psikologi Kependidikan, Bandung: Remaja Rosda Karya

Depdiknas. 2006. Kurikulum 2006 (Pendidikan Dasar dan Menengah). Jakarta: Depdiknas

Dimyati dan Mudjiono. 2009. Belajar dan Pembelajaran. Jakarta: PT Rineka Cipta.

Hamalik, Oemar. 2006. Proses Belajar Mengajar. Jakarta: PT Bumi Aksara

Harsono. 1998. Coaching dan Aspek-Aspek Psikologis dalam Coaching. CV. Tambak Kesuma Jakarta.

Imam Hidayat dalam Agus Mahendra. 2000. Senam. Jakarta: Depdikbud Dirjen Pendidikan Dasar dan Menengah bagian Proyek penataran guru SLTP D-III

Mahendra, Agus. 2000. Senam. Jakarta: Depdikbud Dirjen Pendidikan Tinggi Proyek Pembinaan Tenaga Kependidikan.

Mudjiono Dimyati. 2009. Belajar dan Pembelajaran, Jakarta: Direktorat Jenderal Perguruan Tinggi Depdikbud.

Sardiman, A.M. 2011. Iteraksi \& Motivasi Belajar Mengajar. Jakarta: Rajawali Pers

Sudjana, N. 2010. Penilaian Hasil Proses Belajar Mengajar. Bandung: PT Remaja Rosdakarya.. 